\title{
A Comparative Study on Biomass Fuel Consumption, Collection and Preference Patterns by Rural Households of Forest and Non-Forest Areas in Northern Bangladesh
}

\author{
MD. AHOSAN HABIB ADOR*, MANTAJUR RAHMAN \& NARAYAN SAHA \\ Department of Forestry and Environmental Science, School of Agriculture and Mineral Sciences, Shahjalal \\ University of Science and Technology, Sylhet-3114, Bangladesh \\ *Corresponding author: a_h_ador@yahoo.com \\ Received: 9 September $2020 \quad$ Accepted: 1 December $2020 \quad$ Published: 31 December 2020
}

\begin{abstract}
Biomass fuel is the most important form of renewable energy in many parts of the world including Bangladesh. Its extraction is considered as a leading cause of forest degradation of developing countries like Bangladesh. Its consumption, collection and preference patterns are thus very important indicators of overexploitation of forest. On the other hand, forests are meager in mainly northern region of Bangladesh. Reliable data and information are scanty on biomass fuel in Bangladesh, particularly in formulating its proper management plan. The aim of this study was to conduct a comparative study on the aforesaid patterns in forest and non-forest areas of northern region of Bangladesh. The study was carried out by adaptive multistage random sampling technique. A total of 90 households ( 45 from forest area, 45 from non-forest area) were selected randomly and based on the monthly income the households were categorized into rich, medium, poor groups. The consumption of biomass fuel was found to be differed significantly between forest $(2.10 \mathrm{~kg} / \mathrm{capita} / \mathrm{day})$ and non-forest $(1.71 \mathrm{~kg} / \mathrm{capita} / \mathrm{day})$ area. Forest, market, agriculture, homestead and roadside plantation were identified as sources of biomass fuel, and the contribution of each sources varied significantly between the areas except market. In forest area, maximum amount of biomass fuel was collected from nearby forests (44\%) and poor households collected $78 \%$ of biomass fuels from the same sources. In non-forest area, roadside plantation (31\%) and homesteads (24\%) were the major sources of biomass fuel, and poor households collected biomass fuel mainly from roadside plantations (75\%). Stems, branches, leaves, agricultural residues and cow dung were used as biomass fuel in both areas but the consumption of each biomass fuel types varied significantly except leaves. Women were identified as major biomass fuel collector and most of the biomass fuel was found to be collected during morning to noon in both areas. Most commonly used fuelwood species was Shorea robusta in forest area and Eucalyptus camaldulensis in non-forest area. The findings of this study will help policymakers to take steps in halting deforestation as well as meeting the villager's needs for biomass fuel.
\end{abstract}

Keywords: Bangladesh, biomass fuel, forest degradation, fuelwood, homesteads, natural forests

Copyright : This is an open access article distributed under the terms of the CC-BY-NC-SA(Creative Commons Attribution-Non Commercial-Share Alike 4.0 International License) which permits unrestricted use, distribution, and reproduction in any medium, for non-commercial purposes, provided the original work of the author(s) is properly cited.

\section{INTRODUCTION}

Biomass, the total of non-fossil organic materials that have intrinsic chemical energy content, derived from carbon based materials and mainly comprised of agricultural residues, animal manures, agro-industrial residues, municipal solid wastes and harvests from forests (Balat \& Ayar, 2005; Hossain \& Charpentier, 2015). Biomass energy is the largest source of renewable energy representing $77.78 \%$ of renewable global energy supply and $10 \%$ of global primary energy supply (WEC, 2016). Biomass fuel is the most potential indigenous source of energy and provides almost $35 \%$ of primary energy demand in developing countries (Balat, 2006; Demirbas, 2006). In some developing countries, it accounts for more than $90 \%$ of total rural energy source (Demirbas \& Demirbas, 2007). It is still the main energy source in many developing countries (e.g. Nepal 97\%, Bhutan $86 \%$, Africa 39\%) and mainly fuelwood is used as bio-energy in those countries for cooking 
and heating (Hoogwijk et al., 2005).

Bangladesh is one of the most densely populated country in the world with 161.38 million people (WPP, 2019). Traditional biomass fuels are predominant sources of rural energy to meet cooking, commercial, and industrial needs in Bangladesh, mainly in the form of agricultural residues $(46 \%)$, wood wastes $(34 \%)$, and animal dung (20\%) (Rahman et al., 2013; Huda et al., 2014; Islam et al., 2014). Homestead, agriculture and plantation are main sources of biomass fuel and about $76 \%$ of rural fuel demand is supplied by biomass of which $74 \%$ are collected from agriculture and homestead (Akther et al., 2010). The collection of biomass fuel is unsustainable (Hassan et al., 2012) and overexploitation of natural and homestead forests is potentially sharing deforestation and day by day the shortage intensity is being increased across the country (Akther et al., 2010).

The extraction and utilization of biomass fuel depend on demographic and socio-economic factors of households and varies from village to village, region to region and country to country. In Bangladesh, different aspects of biomass fuel have been studied by various researchers. Kennes $e t$ al. (1984) assessed the quantitative description of biomass energy situation by various socioeconomic groups of Bangladesh. Bari et al. (1998) studied the biomass energy supply and use at village levels using three methods in Mymensingh and Kishoreganj district. Miah et al. (2003) assessed biomass fuel used by the rural households in Chittagong region. Jashimuddin et al. (2006) investigated the consumption of biomass fuel and preference pattern in disregarded villages of Sandwip and Noakhali Sadar upazila. Miah et al. (2010) investigated the consumption of energy by rural households in disregarded villages of Chandanaish upazila of Chittagong district. Miah et al. (2011) compared domestic energy use pattern of rural and semi-urban area of Noakhali district. Chowdhury et al. (2011) described biomass fuel use and burning techniques by forest user groups of Rema kalenga Wildlife Sanctuary. Halder et al. (2014) conducted research on the resources of biomass energy and practices of related technologies in Bangladesh. Baul et al. (2018) compared energy consumption and related emission from renewable (biomass) and nonrenewable sources in Bangladesh. Alam et al (2019) investigated biomass fuel consumption pattern at household level in northern region of Bangladesh. But no comparative study on biomass fuel situation of forest and non-forest sources were carried out. There is a lack of reliable information on biomass fuel to meet up its demand-supply gap. Considering these view-points, the study was undertaken to compare per capita biomass fuel consumption by rural households of forest and nonforest area in the northern region of Bangladesh. The study also explored the types and sources of biomass fuel, and figured out the collection pattern of biomass fuel in both study areas.

\section{MATERIALS AND METHODS}

Two study areas were selected purposively, one for representing the forest area and another for the nonforest area. Birganj upazila (sub-district) of Dinajpur district and Ulipur upazila (sub-district) of Kurigram district were selected as forest area and non-forest area respectively (Figure 1). Birganj National Park and Singra National Park are located in Birganj upazila, while no forest is located in Ulipur upazila. Birganj Upazila is located in between $25^{\circ} 48^{\prime}$ and $26^{\circ} 04^{\prime} \mathrm{N}$ latitudes and in between $88^{\circ} 29^{\prime}$ and $88^{\circ} 44^{\prime}$ E longitudes (Banglapedia, 2012a). Ulipur Upazila is located in between $25^{\circ} 33^{\prime}$ and $25^{\circ} 49^{\prime} \mathrm{N}$ latitudes and in between $89^{\circ} 29^{\prime}$ and $89^{\circ} 51^{\prime}$ E longitudes (Banglapedia, 2012b). In Bangladesh a district has some upazilas, an upazila is composed of some unions, a union is composed of some Villages. Birganj upazila covering an area of $413.11 \mathrm{sq} \mathrm{km}$ which consists of 11 unions, 187 Villages. The total number of households is 73,895 and average household size is 4.27 . The total population of Birganj upazila is 317,253 and the rate of literacy is 48.05 (BBS, 2011). Ulipur upazila covering an area of $458.48 \mathrm{sq} \mathrm{km}$ which consists of 13 unions, 354 villages. Total number of households is 103,061 and an average size of the household is 3.83. The total population of Ulipur upazila is 395,707 populations and the rate of literacy is 45.6 (BBS, 2011).

An adaptive multistage random sampling technique was applied to locate the villages and households where upazila was considered as primary sampling unit and households as ultimate sampling unit. The sequence of selection for this study was upazila to union, union to village, village to household. Vognagar union of Birganj upazila and Buraburi union of Ulipur upazilla were selected randomly. Adibashipara, Atharopaika 

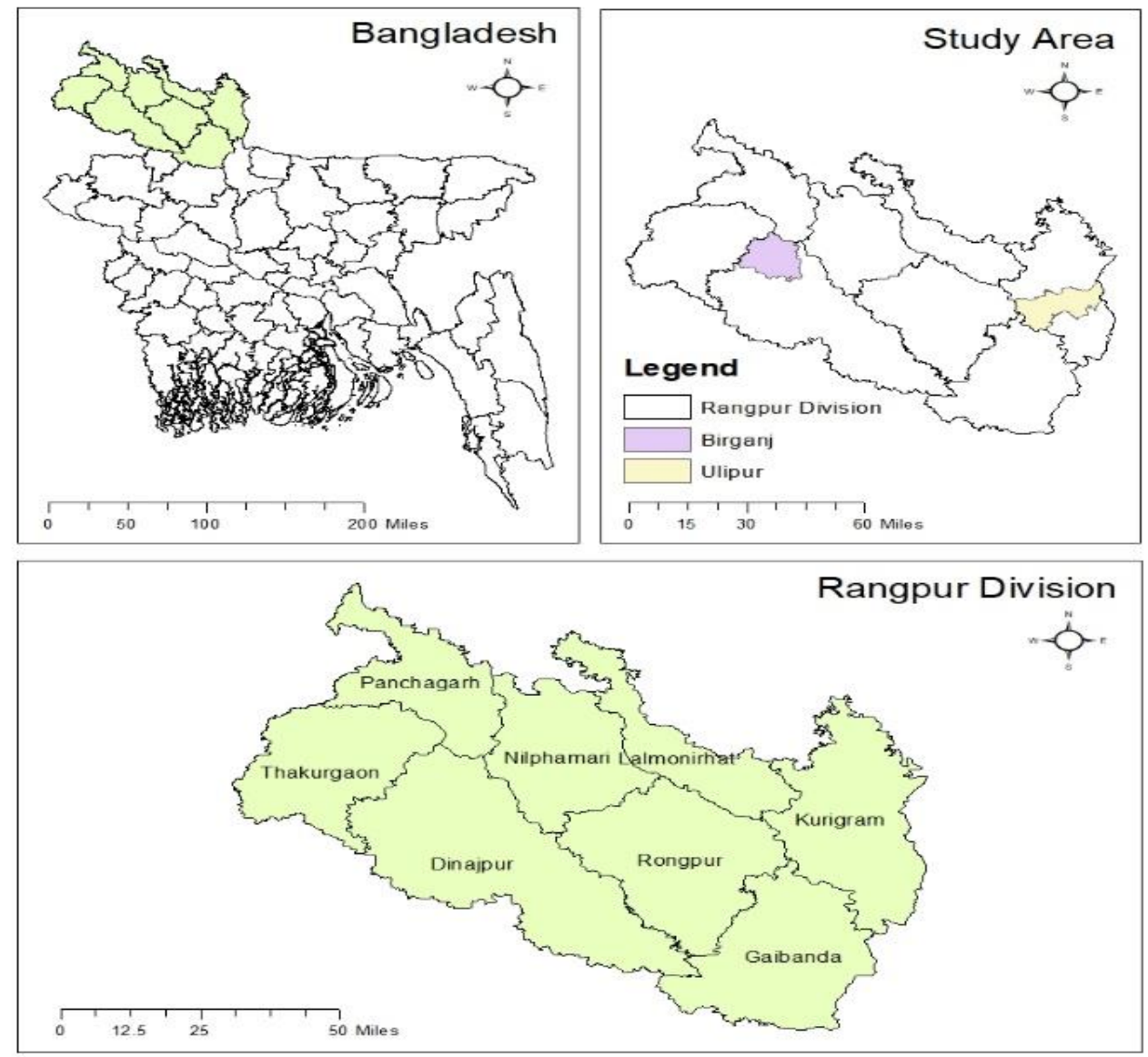

Figure 1. Map of the study areas

were selected randomly among the villages of Vognagar union and Buraburi union, respectively.

The survey was done by a semi-structured questionnaire after completion of a reconnaissance survey. According to preliminary survey the households of both study areas were divided into 3 categories based on the monthly income of the households: poor (less than 10000 BDT), medium (10000-15000 BDT), rich (more than 15000 BDT). A total of 90 households ( 15 from each category of each area) were selected randomly. The quantity of collection and consumption of biomass fuel was recorded daily basis in local units, later it was converted to kilogram. The survey was conducted from October-December (2019) and data were collected from last ten days of first months, second ten days of second month and first ten days of last month. A paired ranking exercise was also conducted after the interview to find out the fuelwood species were preferred by the respondents. Among the respondents $74 \%$ were female, $26 \%$ were male in forest area while $66 \%$ were female, $34 \%$ were male in non-forest area. A total of $63 \%$ respondents were illiterate and another $37 \%$ were literate in forest area on the other hand $46 \%$ of the respondents were illiterate and $54 \%$ were literate in non-forest area. The respondents age classes also varied, with $49 \%$ were above 50 years, $31 \%$ were $30-50$ years, $20 \%$ were below 30 years in forest area while in non-forest area, $34 \%$ of the respondents were above 50 years, $37 \%$ were $30-50$ years, $29 \%$ were below 30 years. Finally, all the data were cross checked in a group meeting at each village involving the people of various level.

The data was analyzed using Microsoft Excel (2013) and SPSS (23.0). ArcGis (10.8) was used for creating the map of the study area. One way analysis of variance (ANOVA) was used for examining significant difference of the variables between forest and non-forest area. ANOVA was also carried out for determining the significant difference of variables between the income groups of each area. Duncan's Multiple Range Test (DMRT) was conducted for identifying significant difference between variables within the forest and non-forest area. 


\section{RESULTS}

\section{Consumption of Biomass Fuel}

Different income groups were found to be consumed various amount of biomass and per capita biomass fuel consumption differed significantly between forest and non-forest area. (Table 1) The average biomass fuel consumption of forest area was found to be $2.10 \mathrm{~kg} / \mathrm{capita} /$ day. ANOVA indicated biomass fuel consumption of forest area varied significantly $(\mathrm{F}=9.69, \mathrm{P}<0.001)$ between the income groups and DMRT revealed only the consumption of poor income group significantly $(\mathrm{p}<0.05)$ differed from medium and rich income group (Table 1). In non-forest area, average consumption of biomass fuel was 1.71 (kg/capita/day). The consumption between the income groups of non-forest area differed significantly $\quad(\mathrm{F}=3.25, \quad \mathrm{P}<0.05)$ and DMRT determined biomass fuel consumption between poor and rich income groups varied significantly $(p<0.05)$ while the consumption of medium income group did not differ significantly either with poor or rich income group (Table 1). The maximum amount of biomass fuel was consumed by poor households both in forest $(2.28 \mathrm{~kg} / \mathrm{capita} / \mathrm{day})$ and non-forest $(1.81 \mathrm{~kg} / \mathrm{capita} /$ day $)$ area while less amount of biomass fuel was consumed by rich households both in forest area $(1.89 \mathrm{~kg} / \mathrm{capita} /$ day $)$ and non-forest area (1.57 kg/capita/day) (Table 1).

\section{Types of Biomass Fuel Used}

The respondents of the study areas were asked to report on different types of biomass fuel for household use only. The stems, branches, leaves, agricultural residues, cow dung were the different types of biomass fuel used. The overall consumption of these types of biomass fuel varied significantly between forest area and non-forest area except leaves (Table 2). ANOVA determined that consumption of different types of biomass fuel significantly $(\mathrm{P}<0.001)$ varied between income groups of both forest and non-forest area and DMRT revealed the consumption of all these types of biomass fuel differed significantly $(\mathrm{p}<0.05)$ among the income groups of both areas (Table 3). Stems of trees were used as a major type of biomass fuel in both forest area (43\%) and non-forest area (33\%) (Table 3). In the forest area, branches of trees $(23 \%)$ occupied the second-largest position as a type of biomass fuel used followed by leaves of trees $(21 \%)$, agricultural residues (7\%), cow dung $(6 \%)$ while in non-forest area, agricultural residues (21\%) obtained the second largest position followed by leaves of trees (17\%), branches of trees (15\%) and cow dung (14\%) (Table 3). Rich households of forest area mainly consumed stems (72\%), branches (15\%), while medium households consumed stems $(45 \%)$, branches $(21 \%)$ and poor households consumed leaves (41\%), branches (33\%) (Table 3). Whereas in non-forest area, rich households mainly met biomass fuel needs as stems

Table 1. Average biomass fuel consumption by the households of the study areas

\begin{tabular}{ccc}
\hline Income Groups & $\begin{array}{c}\text { Biomass Fuel Consumption } \\
(\mathrm{kg} / \text { capita/day })\end{array}$ & $\begin{array}{c}\text { Average } \\
(\mathrm{kg} / \text { capita/day })\end{array}$ \\
\hline & Forest Area & \\
Poor & $2.28( \pm 0.20) \mathrm{a}$ & $2.10( \pm 0.30)^{* * *}$ \\
Medium & $2.14( \pm 0.17) \mathrm{b}$ & \\
Rich & $1.89( \pm 0.33) \mathrm{b}$ & \\
Poor & Non-forest Area & $1.71( \pm 0.29)^{*}$ \\
Medium & $1.81( \pm 0.25) \mathrm{a}$ & \\
Rich & $1.74( \pm 0.26) \mathrm{ab}$ & \\
\hline
\end{tabular}

Note: Same letter(s) in the same column were not significantly $(\mathrm{p}<0.05)$ different according to DMRT. Asterisks indicated significant $(* \mathrm{p}<0.05$, ** $\mathrm{p}<0.01$, *** $\mathrm{p}<0.001)$ difference of the variable(s) between the income groups according to ANOVA. Value inside the first bracket indicated standard deviation. 
Table 2. Analysis of variance (ANOVA) of the variables between forest and non-forest area

\begin{tabular}{lcc}
\hline Variables & F Value & P value \\
\hline $\begin{array}{l}\text { Biomass fuel consumption } \\
\text { (kg/capita/day) }\end{array}$ & 41.56 & $<0.001$ \\
\hline Sources of biomass fuel & 112.83 & $<0.001$ \\
Forest & 0.001 & 0.973 \\
Market & 45.24 & $<0.001$ \\
Agriculture & 10.53 & 0.002 \\
Homestead & 20.97 & $<0.001$ \\
Roadside plantation & & \\
\hline Types of biomass fuel & 4.15 & 0.045 \\
Stems & 13.97 & $<0.001$ \\
Branches & 1.72 & 0.192 \\
Leaves & 43.97 & $<0.001$ \\
Agricultural residues & 8.37 & 0.005 \\
Cow dung & & \\
\hline
\end{tabular}

(60\%), agricultural residues (23\%), medium households as stems $(35 \%)$, agricultural residues $(30 \%)$ and poor households as cow dung (34\%), leaves $(33 \%)$ (Table 3$)$.

\section{Sources of Biomass Fuel}

Total five sources of biomass fuel were identified in both study areas, as forest, roadside plantation, homestead, market and agriculture. Among the sources, overall contribution of forest, agriculture, homestead and roadside plantation significantly differed between forest and non-forest area except market (Table 2). ANOVA revealed the contribution of all sources varied significantly $(p<0.001)$ between the income groups of both areas and DMRT determined the significant $(\mathrm{p}<0.05)$ difference of the contribution of each sources between the income groups of both forest and nonforest areas (Table 4). In forest area, the maximum amount of biomass fuel was collected from forest (44\%) while less amount was collected from agriculture (5\%). In non-forest area, maximum amount of biomass fuel was contributed by roadside plantation $(31 \%)$ followed by market (28\%), homestead (24\%) and agriculture (17\%) (Table 4). Poor households of forest area collected biomass fuel mainly from forest $(78 \%)$ while poor households of non-forest area mainly collected biomass fuel from roadside plantation (75\%) (Table 4). Market contributed the maximum amount of biomass fuel for rich households of both forest area $(59 \%)$ and non-forest area $(48 \%)$ while medium households of both areas collected

Table 3. Different types of biomass fuel (\%) used by the households of the study areas

\begin{tabular}{|c|c|c|c|c|c|}
\hline Income Groups & Stems & Branches & Leaves & $\begin{array}{l}\text { Agricultural } \\
\text { residues }\end{array}$ & Cow dung \\
\hline \multicolumn{6}{|l|}{ Forest Area } \\
\hline Poor & $13( \pm 7.17) \mathrm{a}$ & $33( \pm 10.39) \mathrm{a}$ & $41( \pm 7.34) \mathrm{a}$ & $2( \pm 2.67) \mathrm{a}$ & $11( \pm 7.65) \mathrm{a}$ \\
\hline Medium & $45( \pm 11.21) b$ & $21( \pm 8.91) b$ & $14( \pm 6.90) \mathrm{b}$ & $16( \pm 6.91) b$ & $4( \pm 4.70) b$ \\
\hline Rich & $72( \pm 21.05) \mathrm{c}$ & $15( \pm 6.40) \mathrm{b}$ & $8( \pm 6.56) c$ & $3( \pm 3.09) \mathrm{a}$ & $2( \pm 3.03) b$ \\
\hline Average & $43( \pm 28.07) * * *$ & $23( \pm 11.39)^{* * *}$ & $21( \pm 16.02)^{* * *}$ & $7( \pm 7.88)^{* * *}$ & $6( \pm 6.67)^{* * *}$ \\
\hline \multicolumn{6}{|l|}{ Non-forest Area } \\
\hline Poor & $3( \pm 2.72) \mathrm{a}$ & $20( \pm 5.60) \mathrm{a}$ & $33( \pm 4.51) \mathrm{a}$ & $10( \pm 5.38) \mathrm{a}$ & $34( \pm 17.25) \mathrm{a}$ \\
\hline Medium & $35( \pm 6.23) b$ & $15( \pm 5.63) b$ & $12( \pm 5.38) b$ & $30( \pm 5.08) \mathrm{b}$ & $8( \pm 6.22) b$ \\
\hline Rich & $60( \pm 12.21) c$ & $11( \pm 4.30) \mathrm{c}$ & $6( \pm 4.79) c$ & $23( \pm 5.86) b$ & $0( \pm 0.00) \mathrm{c}$ \\
\hline Average & $33( \pm 25.24) * * *$ & $15( \pm 6.67)^{* * *}$ & $17( \pm 12.65)^{* * * *}$ & $21( \pm 7.85) * * *$ & $14( \pm 17.95) * * *$ \\
\hline
\end{tabular}

Note: Same letter(s) in the same column were not significantly $(\mathrm{p}<0.05)$ different according to DMRT. Asterisks indicated significant $(* \mathrm{p}<0.05, * * \mathrm{p}<0.01, * * * \mathrm{p}<0.001)$ difference of the variable(s) between the income groups according to ANOVA. Value inside the first bracket indicated standard deviation. 
Table 4. Sources (\%) of biomass fuel for the households of the study areas

\begin{tabular}{lccccc}
\hline $\begin{array}{l}\text { Income } \\
\text { Groups }\end{array}$ & Forest & Market & Agriculture & Homestead & Roadside Plantation \\
\hline Forest Area & $78( \pm 11.20) \mathrm{a}$ & $0( \pm 0.00) \mathrm{a}$ & $2( \pm 1.92) \mathrm{a}$ & $8( \pm 5.01) \mathrm{a}$ & $12( \pm 5.81) \mathrm{a}$ \\
$\begin{array}{l}\text { Poor } \\
\text { Medium }\end{array}$ & $39( \pm 8.85 \mathrm{~b}$ & $25( \pm 11.82) \mathrm{b}$ & $11( \pm 7.96) \mathrm{b}$ & $17( \pm 8.72) \mathrm{b}$ & $8( \pm 6.80) \mathrm{b}$ \\
Rich & $15( \pm 8.51) \mathrm{c}$ & $59( \pm 35.14) \mathrm{c}$ & $2( \pm 1.81) \mathrm{a}$ & $24( \pm 9.70) \mathrm{b}$ & $0( \pm 0.00) \mathrm{c}$ \\
Average & $44( \pm 27.95)^{* * *}$ & $28( \pm 32.27)^{* * *}$ & $5( \pm 6.38)^{* * *}$ & $16( \pm 10.12)^{* * *}$ & $7( \pm 7.13)^{* * *}$ \\
\hline $\begin{array}{l}\text { Non-forest Area } \\
\text { Poor }\end{array}$ & $0( \pm 0.00)$ & $0( \pm 0.00) \mathrm{a}$ & $10( \pm 6.72) \mathrm{a}$ & $15( \pm 9.21) \mathrm{a}$ & $75( \pm 16.33) \mathrm{a}$ \\
Medium & $0( \pm 0.00)$ & $37( \pm 13.94) \mathrm{b}$ & $26( \pm 9.25) \mathrm{b}$ & $20( \pm 8.01) \mathrm{a}$ & $17( \pm 11.64) \mathrm{b}$ \\
Rich & $0( \pm 0.00)$ & $48( \pm 33.10) \mathrm{b}$ & $16( \pm 8.72) \mathrm{a}$ & $36( \pm 7.02) \mathrm{b}$ & $0( \pm 0.00) \mathrm{c}$ \\
Average & $0( \pm 0.00)$ & $28( \pm 29.01) * * *$ & $17( \pm 10.5) * * *$ & $24( \pm 10.94)^{* * *}$ & $31( \pm 34.42)^{* * *}$ \\
\hline
\end{tabular}

Note: Same letter(s) in the same column were not significantly $(\mathrm{p}<0.05)$ different according to DMRT. Asterisks indicated significant $(* \mathrm{p}<0.05, * * \mathrm{p}<0.01, * * * \mathrm{p}<0.001)$ difference of the variable(s) between the income groups according to ANOVA. Value inside the first bracket indicated standard deviation.

biomass fuel from all sources on average (Table 4).

\section{Collection of Biomass Fuel}

Female was identified as predominant collectors of biomass fuel from forest, roadside plantation, homestead and agriculture in both areas. 52\% of biomass fuel of forest area and $65 \%$ of biomass fuel of non-forest area were collected by the female (Figure 2a). In forest area, male (35\%) obtained the second major biomass fuel collector followed by children $(13 \%)$, while in non-forest area, children (22\%) occupied the second position followed by the male (13\%) (Figure 2a). Most of the biomass fuel was collected during morning and noon in both areas. In the forest area, $61 \%$ of biomass fuel was collected in the noon followed by morning (22\%), afternoon (17\%) while in non-forest area, $51 \%$ of biomass fuel was collected in the morning followed by noon (40\%), afternoon (9\%) (Figure 2b).

\section{Species Used as Biomass Fuel}

A list of 39 species (tree and shrub) was identified as various parts of these were mostly used as biomass fuel in the study areas (Table 5). In forest area, Shorea robusta (90\%) was most commonly used species followed by Acacia auriculiformis (78\%), Eucalyptus camaldulensis (63\%), Bambusa sp. (58\%), Melia azedarach (53\%), Mangifera indica (45\%), Samanea saman (40\%), Litchi chinensis (28\%), Artocarpus heterophyllus (20\%), Swietenia macrophylla (15\%) (Figure c). In nonforest area, Eucalyptus camaldulensis (80\%) was most used species as biomass fuel followed by Lannea coromandelica (70\%), Trewia nudiflora (65\%), Bambusa sp. (58\%), Acacia auriculiformis (45\%), Mangifera indica (45\%), Albizia procera (35\%), Artocarpus heterophyllus (30\%), Swietenia macrophylla (23\%), Neolamarckia cadamba (13\%) (Figure 3).
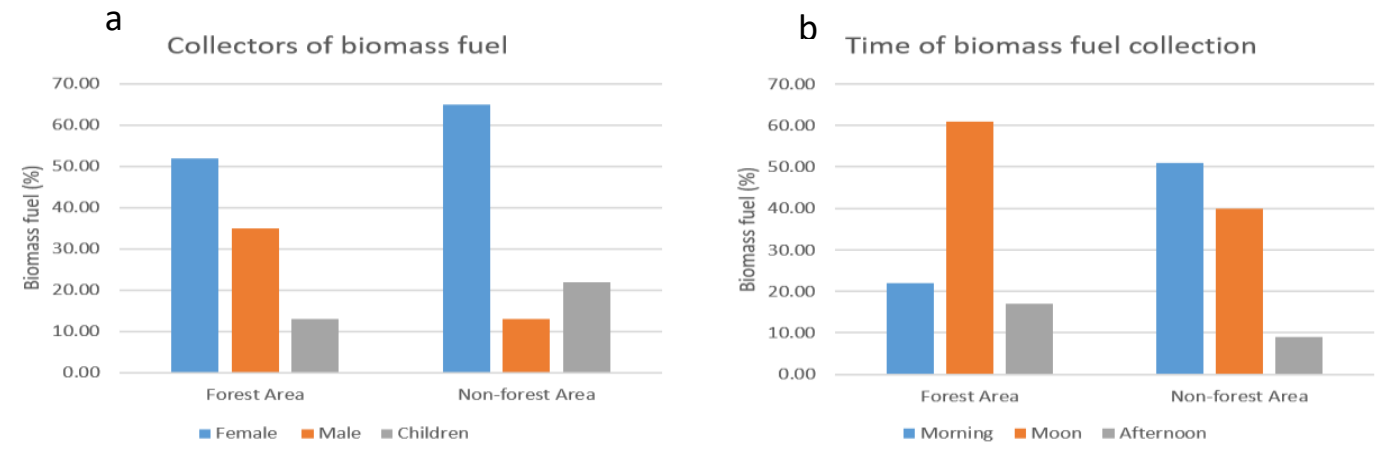

Figure 2. Collectors of biomass fuel (a) and time of biomass fuel collection (b) in the study areas 
Table 5. Species used as biomass fuel in the study areas

\begin{tabular}{|c|c|c|c|}
\hline \multicolumn{2}{|c|}{ Forest Area } & \multicolumn{2}{|c|}{ Non-forest Area } \\
\hline Local Name & Scientific Name & Local Name & Scientific Name \\
\hline $\begin{array}{l}\text { Akashmoni } \\
\text { Am }\end{array}$ & $\begin{array}{c}\text { Acacia auriculiformis } \\
\text { Mangifera indica }\end{array}$ & $\begin{array}{l}\text { Akashmoni } \\
\text { Am }\end{array}$ & $\begin{array}{c}\text { Acacia auriculiformis } \\
\text { Mangifera indica }\end{array}$ \\
\hline Amloki & Phyllanthus emblica & Bas & Bambusa sp. \\
\hline Bahera & Terminalia bellirica & Boroi & Ziziphus maurutiana \\
\hline Bas & Bambusa sp. & Chalta & Dillenia indica \\
\hline Chapalish & Artocarpus chaplasha & Dogli/Pitali & Trewia nudiflora \\
\hline Dumur & Ficus hispida & Eucalyptus & Eucalyptus camaldulensis \\
\hline Eucalyptus & Eucalyptus camaldulensis & Henda & Ricinus communis \\
\hline Gamar & Gmelina arborea & Jam & Syzygium cumini \\
\hline Ghora-neem & Melia azedarach & Jhiga & Lannea coromandelica \\
\hline Guti-jam & Syzygium jambos & Kadam & Neolamarckia cadamba \\
\hline Jarul & Lagerstroemia speciosa & Kash & Saccharum spontaneum \\
\hline Jolpai & Elaeocarpus serratus & Kathal & Artocarpus heterophyllus \\
\hline Kadam & Neolamarckia cadamba & Kodbel & Limonia acidissima \\
\hline Kathal & Artocarpus heterophyllus & Silkoroi & Albizia procera \\
\hline Lichu & Litchi chinensis & Mehogoni & Swietenia macrophyll \\
\hline Mangium & Acacia mangium & Neem & Azadirachta indica \\
\hline Mehogoni & Swietenia macrophyll & Pakor & Ficus rumphii \\
\hline Minjiri & Senna siamea & Peyara & Psidium guajava \\
\hline Raintree & Samanea saman & Raintree & Samanea saman \\
\hline Sal & Shorea robusta & Segun & Tectona grandis \\
\hline Segun & Tectona grandis & Shimul & Bombax ceiba \\
\hline Shimul & Bombax ceiba & Sissoo & Dalberzia sissoo \\
\hline Silkoroi & Albizia procera & Sonalu & Cassia fistula \\
\hline Sonalu & Cassia fistula & Supari & Areca catechu \\
\hline Supari & Areca catechu & Tetul & Tamarindus indica \\
\hline
\end{tabular}
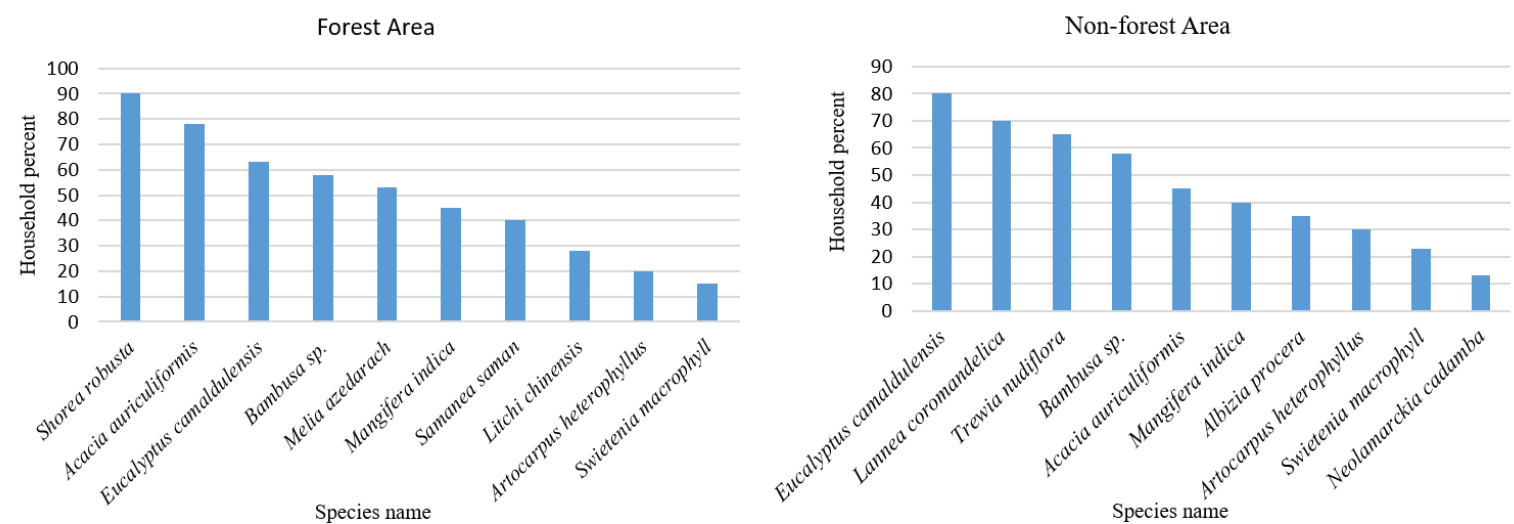

Figure 3. Preference of species for biomass fuel in the study area 


\section{DISCUSSION}

The present study provided a comparative overview of biomass fuel consumption, collection and preference patterns of forest area and nonforest areas in the rural northern region of Bangladesh. The method of this study was similar to previous studies (Akther et al., 2010; Hassan et al., 2012; Alam et al., 2019). Income is a determinant of social class and it enforces the way of life and biomass fuel consumer behavior, hence household income was the main consideration rather than other demographic profiles for grouping the households into various categories following Miah et al. (2003). The moisture content of biomass fuel was not always considered, therefore, the result of this study is an approximation and may not always be accurate. The present study revealed significant difference of per capita biomass fuel and the mean biomass fuel consumption was $2.10 \mathrm{~kg} /$ capita/day and 1.71 $(\mathrm{kg} / \mathrm{capita} /$ day $)$ in forest area and non-forest area, respectively. Bhatt and Sachan (2004) reported maximum and minimum biomass fuel consumption $2.80 \mathrm{~kg} / \mathrm{capita} / \mathrm{day}$ and 1.07 $\mathrm{kg} / \mathrm{capita} /$ day respectively for households of different mountain villages of India while Kandel et al. (2016) reported $1.70 \mathrm{~kg} / \mathrm{capita} /$ day for the rural households of community forest user groups of Nepal and the finding of the present study is corroborated with these previous studies. Rich households of both areas were found using LPG gas, electricity for cooking and heating while poor households have no such kind of options. Besides few rich households were also found using developed stove but all medium and poor households were found using traditional stoves only. Therefore, rich households of both areas consumed less amount of biomass fuel compared to poor and medium households.

The households of both forest and non-forest area used stems, branches, leaves, agricultural residues, cow dung as biomass fuel that consisted with the findings of Jashimuddin et al. (2006), Asaduzzaman et al. (2010) and Miah et al. (2010). Though the households of both areas used same components of biomass fuel, the present study revealed significant different patterns of biomass fuel consumption among the income groups of both areas. All the respondents opined that mainly household income, availability and accessibility to different types of biomass fuel brought about different consumption pattern. Maximum amount of stems and branches alone (87\% in forest area, $71 \%$ in non-forest area) consumed by rich households while maximum of amount of leaves, agricultural residues, cow dung alone $(54 \%$ in forest area, $77 \%$ in non-forest area) used by poor households and medium households consumed all types of biomass fuel on average. The finding of the present study is abrogated with Miah et al. (2003) that rich households consumed maximum amount of stems and branches alone (94\%) while medium households consumed branches and leaves alone $(77 \%)$ and poor households consumed leaves and agricultural residues alone (54\%) in Chittagong region of Bangladesh. The households of forest area depended on the forest for biomass fuel and average $44 \%$ of total biomass fuel was contributed by forest while in non-forest-area the contribution of the forest was quenched by agriculture (17\%) and roadside plantation $(31 \%)$. The contribution of market was significantly same on average (28\%) for both areas and homestead contributed average $8 \%$ more in non-forest area than forest area. All income groups did not have the same access to all sources of biomass fuel. Rich households had the ability to buy biomass fuel and almost all of them had a large homestead, but poor groups were mostly landless and did not have ability to buy. The rich households collected maximum amount of biomass fuel from market (59\% in forest area, $48 \%$ in non-forest area) and homestead (24\% in forest area, 36\% in non-forest area). Poor households of forest area collected $78 \%$ of biomass fuel from forest while poor households of non-forest area collected $75 \%$ of biomass fuel from a roadside plantation. Medium households collected biomass fuel from all sources on average. Miah et al. (2003) reported market, homestead, agriculture, plantation contributed average $28 \%$, $33 \%, 15 \%, 25 \%$ respectively and poor households collected $74 \%$ biomass fuel from the plantation, rich households collected $47 \%$ biomass fuel from market medium households collected from all sources averagely in rural areas of Chittagong (Bangladesh) which is almost similar to the present study.

Traditionally, women are mainly responsible for the domestic activities in the rural northern region of Bangladesh, therefore, women were found as major biomass fuel collector for both areas though, other family members helped them in biomass fuel collection. Most of the biomass fuel was collected during morning to noon. It is conceded as convenient time for biomass fuel 
collection by the respondents. Female collected biomass fuel after completing the domestic work in the morning, while male collected when only they got free from professional work. Similar type of gender disproportion in biomass fuel collection by rural households of Bangladesh was also reported by Hassan et al. (2013). The present study identified 39 species (tree, shrub) mostly used as biomass fuel in both study areas. Shorea robusta, Eucalyptus camaldulensis the most commonly used tree species in forest area and non-forest area respectively. The forests of northern Bangladesh is under the classification of tropical moist deciduous forest that mainly composed of Shorea robusta (Khan et al., 2007) and Eucalyptus sp. were planted extensively in the degraded lands and roadsides of northern Bangladesh for diminishing fuel demand since 1977 (Hossain, 2016). The maximal use is possessed due to the availability of these species in the respective area. Alam et al. (2019) identified almost similar species used as biomass fuel in the northern region of Bangladesh and reported Azadirachta indica as most preferred followed by Eucalyptus globules, Bambusa sp., Artocarpus heterophyllus, Mangifera indica, and Swietenia mahagoni.

\section{CONCLUSION}

Despite the phenomenal economic condition of the study areas, the poor and medium households have become a pervasive feature of the biomass fuel consumption. The consumption, collection and preference patterns of biomass fuel significantly varied between forest and non-forest area of rural northern Bangladesh. It is aggravating the current situation of a huge amount of biomass fuel collection and creating a continuous pressure on natural forests and agricultural residues, which are very important components of mainly environmental stability and soil fertility respectively. The preferred tree species for biomass fuel sources indicates the high dependency on both natural forests and homesteads and it is alarming for the green future. The consumption of agricultural residues is also alarming in future agricultural food production. Therefore, immediate actions should be undertaken by the respective authorities to increase roadside plantations in forest areas and keep continuing the present plantation activities in non-forest areas for ensuring rural energy security and promoting sustainable energy supply.

\section{REFERENCES}

Akther, S., Miah, M.D. \& Koike, M. (2010). Domestic use of biomass fuel in rural Meghna floodplain areas of Bangladesh. iForest- Biogeosciences and Forestry, 3: 144-149.

Alam, M., Khan, M.S., Kayes, I. \& Salam, M.A. (2019). Domestic biomass fuel composition pattern in northern part of Bangladesh. Borneo Journal of Sciences and Technology, 1(2): 78-85.

Asaduzzaman, M., Barnes, D.F. \& Khandker, S.R. (2010). Restoring balance: Bangladesh's rural energy realities. World Bank Working Paper No. 181. World Bank, Washington DC, USA.

Balat, M. (2006). Biomass energy and biochemical conversion processing for fuels and chemicals. Energy Sources Part A, 28: 517-25.

Balat, M. \& Ayar, G. (2005). Biomass energy in the world, use of biomass and potential trends. Energy Source, 27: 931-940.

Banglapedia (2012a). National Encyclopaedia of Bangladesh. Asiatic Society of Bangladesh: Dhaka. Retrieved July 18, 2020, from http://en.banglapedia.org/index.php?title=Birganj_ Upazila .

Banglapedia (2012b). National Encyclopaedia of Bangladesh. Asiatic Society of Bangladesh: Dhaka. Retrieved July 18, 2020, from http://en.banglapedia.org/index.php?title=Ulipur_U pazila .

Bari, M.N., Hall, D.O., Lucas, N.J.D. \& Hossain, S.M.A. (1998). Biomass energy use at the household level in two villages of Bangladesh: assessment of field methods. Biomass and Energy, 15(2): 171-180.

Baul, T.K., Datta, D. \& Alam, A. (2018). A comparative study on household level energy consumption and related emissions from renewable (biomass) and non-renewable energy sources in Bangladesh. Energy Policy, 114: 598-608.

BBS (Bangladesh Bureau of Statistics) (2011). In: Population and Housing Census. Statistics Division, Ministry of Planning, Government of the People's Republic of Bangladesh, Dhaka.

Bhatt, B.P. \& Sachan, M.S. (2004). Firewood consumption along an altitudinal gradient in mountain villages of India. Biomass and Bioenergy, 27: 69-75. 
Chowdhury, M.S., Koike, M., Akther, S. \& Mish, M.D. (2011). Biomass fuel use, burning technique and reasons for the denial of improved cooking stoves by forest user groups of Rema-Kalenga wildlife sanctuary, Bangladesh. International Journal of Sustainable Development and World Ecology, 18(1): 88-97.

Demirbas, A. (2006). Global renewable energy resources. Energy Sources Part A: Recovery, Utilization, and Environmental Effects, 28(8): 779792.

Demirbas, A.H. \& Demirbas, I. (2007). Importance of rural bioenergy for developing countries. Energy Conversion and Management, 48: 2386-2398.

Halder, P.K., Paul, N. \& Beg, M.R.A. (2014). Assessment of biomass energy resources and related technologies practice in Bangladesh. Renewable and Sustainable Energy Reviews, 39: 444-460.

Hassan, M.K., Halder, P., Pelkonen, P. \& Pappinen, A. (2013). Rural households' preferences and attitudes towards biomass fuel- results from a comprehensive field survey in Bangladesh. Energy, Sustainability and Society, 3 (24): 1-14.

Hassan, M.K., Pelkonen, P., Halder, P. \& Pappinen, A. (2012). An analysis of cross-sectional variation in energy consumption pattern at the household level in disregarded rural Bangladesh. Journal of Basic Applied Scientific Research, 2(4): 3949-3963.

Hoogwijk, M., Faaij, A., Eickhout, B., de Vries, B. \& Turkenburg, W. (2005). Potential of biomass energy out to 2100, for four IPCC SRES land-use scenarios. Biomass and Bioenergy, 29: 225-257.

Hossain, M.K. (2016). Plantation Forestry: Paradigm to meet the demand of the forestry resources in Bangladesh. In Nath, T.K. \& O'Reily, P. (eds.) Monoculture Farming- Global Practices, Ecological Impact and Benefits/Drawbacks, Nova publishers, New York, pp. 57-74.

Hossain, M.Z. \& Charpentier, P.A. (2015). Hydrogen production by gasification of biomass and opportunity fuels. Compendium of Hydrogen Energy, 1: 137-175.

Huda, A.S.N., Mekhilef, S. \& Ahsan, A. (2014) Biomass energy in Bangladesh: current status and prospects. Renewable and sustainable Energy Review, 30: 504-517.
Islam, A., Chan, E.S., Taufiq-yap, Y.H., Mondal, M.A.H., Moniruzzaman, M. \& Mridha, M. (2014). Energy security in Bangladesh perspective - an assessment and implication. Renewable and sustainable Energy Review, 32: 154-171.

Jashimuddin, M., Masum, K.M. \& Salam, M.A. (2006). Preference and consumption pattern of biomass fuel in some disregarded villages of Bangladesh. Biomass and Energy, 30: 446- 451.

Kandel, P., Chapagain, P.S., Sharma, L.N. \& Vetaas, O.R. (2016). Consumption patterns of fuelwood in rural households of Dolakha district, Nepal: reflections from community forest user groups. Small-scale Forestry, 15(4): 481-495.

Kennes, W., Parikh, J.K. \& Stolwijk, H. (1984). Energy from biomass by socio-economic groups- a case study of Bangladesh. Biomass, 4: 209-234.

Khan, M.A.S.A., Uddin, M.B., Uddin, M.S., Chowdhury, M.S.H. \& Mukul, S.A. (2007). Distribution and status of forests in the tropics: Bangladesh perspective. Pakistan Academy of Sciences, 44(2):145-153.

Miah, M.D., Ahmed, R. \& Uddin, M.B. (2003). Biomass fuel use by rural households in Chittagong region, Bangladesh. Biomass and Energy, 24: 277-283.

Miah, M.D., Foysal, M.A., Koike, M. \& Kobayashi, H. (2011). Domestic energy-use pattern by the households: a comparison between rural and semiurban areas of Noakhali in Bangladesh. Energy Policy, 39: 3757-3765.

Miah, M.D., Kabir, R.R.M.S. \& Koike, M. (2010). Rural household energy consumption pattern in the disregarded villages of Bangladesh. Energy Policy, 38: 997-1003.

Rahman, M.S., Saha, S.K., Khan, M.R.H., Habiba, U. \& Chowdhury, S.M.H. (2013). Present situation of renewable energy in Bangladesh: renewable energy resources existing in Bangladesh. Global Journal of Researches in Engineering, 13(5): 1-7.

WEC (World Energy Council) (2016). World energy resources 2016. London, United Kingdom.

WPP (World Population Prospects) (2019). Department of Economic and Social Affairs, Population Division, United Nations. 